\title{
Some Thoughts on the Risk of Natural Disasters in Ryukyu Archipelago
}

\author{
Ömer Aydan
}

\begin{abstract}
Ryukyu Archipelago is situated on Ryukyu Arc and consists of 6 major islands together with 55 islands of various sizes. Compared to the other parts of Japan, the documented seismic history of Ryukyu Archipelago is not well known. However, there are huge tsunami boulders, which definitely imply mega earthquakes in the vicinity of Ryukyu Archipelago. Furthermore, the archipelago experiences great typhoons every year compared with other parts of Japan. The Ryukyu limestone formation overlaying Shimajiri formation consisting of mudstone, sandstone and tuff cover a huge area in many islands of the archipelago. While large scale sinkholes and cliff failures observed in association with Ryukyu limestone formation, large scale landslides are commonly observed in Shimajiri formation as geotechnical disasters. It is shown that the risk of mega earthquakes, mega-tsunamis, large-scale geotechnical disasters are quite high in addition to super-typhoons in Ryukyu Archipelago.
\end{abstract}

Index Terms-Ryukyu archipelago, natural disaster, risk, earthquake, tsunami, landslides, typhoons.

\section{INTRODUCTION}

Ryukyu Archipelago is situated on the Ryukyu Arc and consists of a chain of islands for a length of $1300 \mathrm{~km}$ between Kyushu Island of Japan and Taiwan. The main islands are Amami-Oshima, Okinawa, Miyako, Ishigaki, Iriomote and Yonaguni from north to south (Fig. 1). The archipelago was returned to Japanese sovereignty in 1972 after occupation by U.S. forces following World War II. Okinawa Main Island (Okinawa Honto) is the largest and most populous island in the Okinawa Prefecture. The capital of the Okinawa Prefecture is Naha on Okinawa Island.

There is a conception that Okinawa Islands is an aseismic region in Japan alhtough it is well-known to be hit often by great-typhoons. A similar conception existed for Kumamoto Prefecture before the 2016 Kumamoto earthquakes. As a result, Kumamoto Prefecture had to revise the seismic design concept for the prefecture. Therefore, there is a necessity to clarify that the Ryukyu Archipelago, on which Okinawa Prefecture is located, is aseismic or not.

\section{TeCtonics, CRUSTAL Deformation AND SEISMicity}

Manuscript received March 7, 2018; revised August 7, 2018. Ömer Aydan is with University of the Ryukyus, Dept. of Civil Engineering, Nishihara, Okinawa, Japan; he is also with Disaster Prevention Research Center for Islands Regions, Nishihara, Okinawa, Japan (e-mail: aydan@tec.u-ryukyu.ac.jp).

\section{A. Tectonics}

Ryukyu arc is considered to be a convergent plate margin where the Philippine Sea plate is subducting beneath the Eurasian plate [1] (Fig. 2). The arc is a rifting fragment of continental crust and it is oriented NE-SW direction and the convergence rate between the Philippine sea plate and the Eurasia plate varies from 5 to $7 \mathrm{~cm} / \mathrm{yr}$.

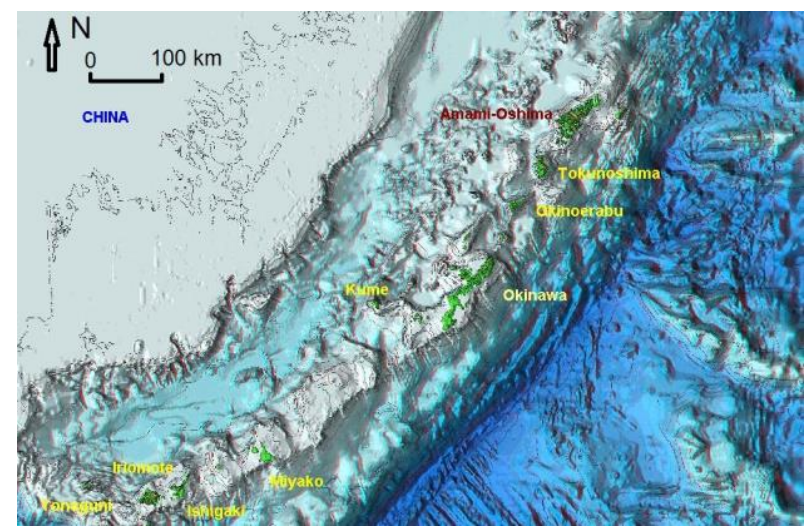

Fig. 1. Ryukyu Archipelago and major islands.

Tectonic evolution since the Neogene is divided into three stages. Stage 1 (late Miocene) is pre-rift sedimentation. Stage 2 (Early Pleistocene) is the initial back-arc rifting. Stage 3 (Holocene) is the back-arc rifting still in progress. The age of the basement is pre-Cenozoic and the basement rocks consist of chert and schists. Cenozoic sandstone, shale and limestone The Ryukyu trench in east and Ryukyu trough in west overlay the basement rocks. These rock units are followed by Pliocene Shimajiri formation and all formations are covered with Quaternary Ryukyu limestone and Holocene deposits.

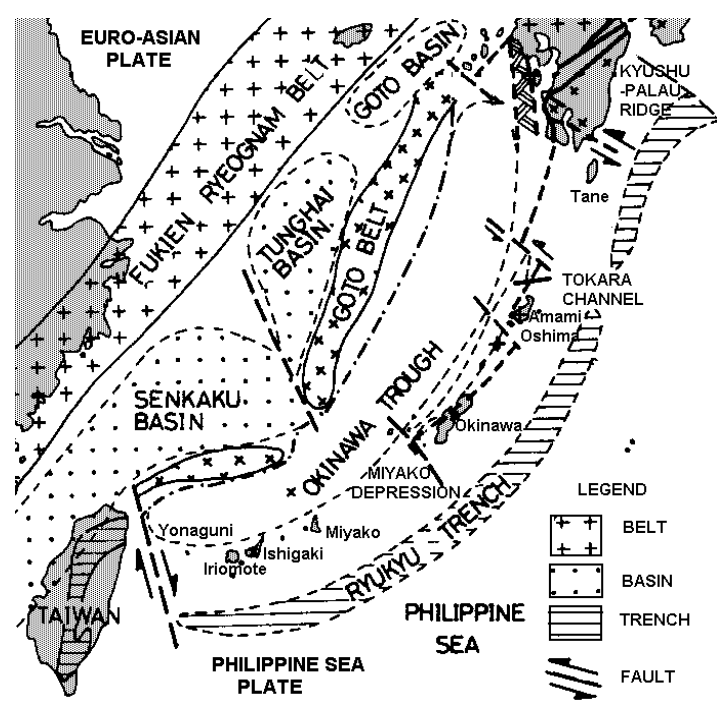

Fig. 2. Tectonics (from Kizaki [1]). 


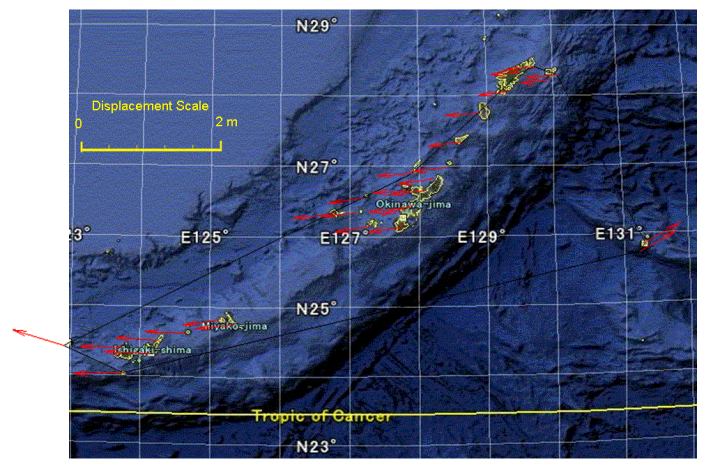

Fig. 3. Annual crustal deformations from GPS.

\section{B. Crustal Deformation}

In the region, the Philippine Sea plate moves towards WNW with respect to the interior of the Eurasia plate, with a relative velocity of approximately $60 \mathrm{~mm} / \mathrm{yr}$. Fig. 3 shows the crustal deformations measured from GPS network of GEONET of Japan and they are used to obtain current crustal straining and stress changes in Ryukyu Archipelago and else where by Aydan et al. [2]-[5]. Aydan [3] developed this method utilizing the principles of Finite Element Method (FEM) to obtain incremental strain and stress changes. Although the GPS stations are sparsely located, it is possible to obtain information on the current situation of crustal straining and stress changes of Ryukyu Islands using Aydan's method.

\section{Seismicity}

The Philippine Sea plate subducts beneath the Eurasia plate at the Ryukyu Trench and is seismically active to depths of about $250 \mathrm{~km}$ (Fig. 4). As seen in Fig. 4(a), the region is very seismically active and there are more than 5 large events having a magnitude greater than 7 in the last 100 years. In view of this seismic activity, it is very difficult to say the Ryukyu Archipelago is an aseismic region.

An earthquake with a local magnitude of 7.2 (Mw 6.9) recently occurred on the east side of Okinawa Island on 2010 Feb. 27 with a strike-slip sense [6]. This earthquake caused some structural damage and the retaining walls of Katsuren Castle and Tama Castle were partially collapsed. Fig. 4(b) shows a seismic activity projected over the vertical cross-section A-A' together with plate-tectonic interpretation. As seen from the figure, the Philippine Sea plate subducts beneath the Okinawa plate-let with an inclination of about 30-35 degrees. On the west side, the seismic activity in Okinawa trough is also clearly seen.

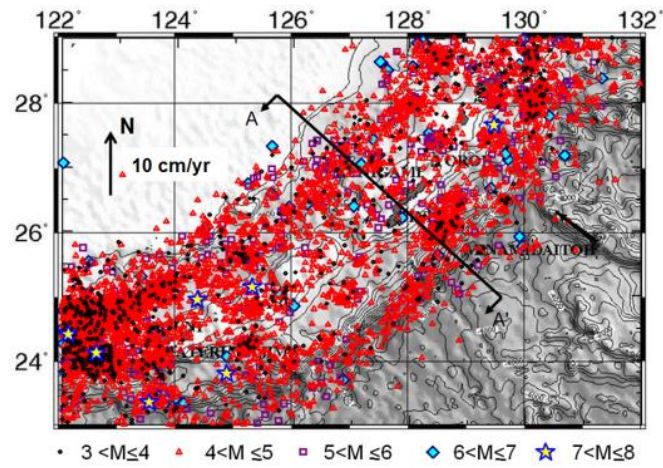

(a) Seismicity the last 100 years [5]

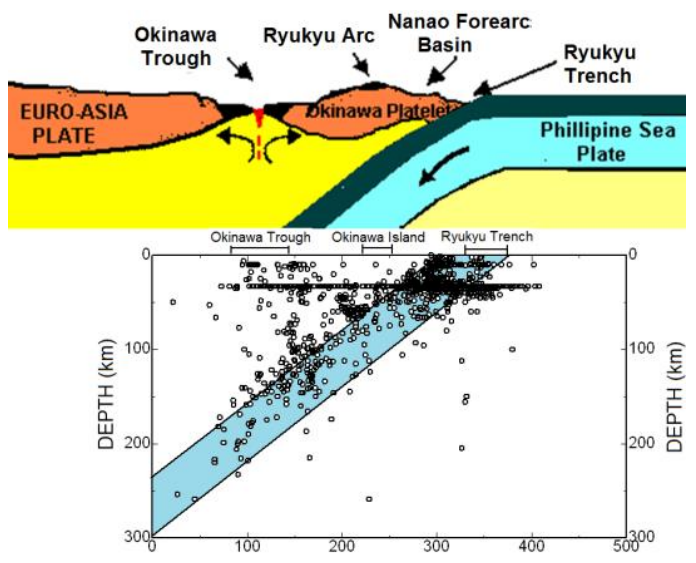

(b) Seismicity on vertical cross section A-A' [6]

Fig. 4. Seismicity of the Ryukyu Archipelago.

\section{EARTHQUAKE RISK}

There is a conception that Okinawa Islands is an aseismic region in Japan alhtough it is well-known to be hit often by great-typhoons. Similar conception existed for Kumamoto Prefecture before the 2016 Kumamoto earthquakes. As a result, Kumamoto Prefecture had to revise the seismic design concept for the prefecture. Therefore, there is a necessity to clarify that the Ryukyu Archipelago, on which Okinawa Prefecture is located, is aseismic or not.

Aydan [7]-[9] proposed some empirical relations between fault length and moment magnitude of earthquakes, which were originally proposed for the earthquakes of Turkey and generalized for world-wide earthquakes in the follow-up publications [10]-[12]. The empirical relation proposed by Aydan [9], [11] and in his follow-up publications [11, [12] for both thrust, strike-slip and normal faults.

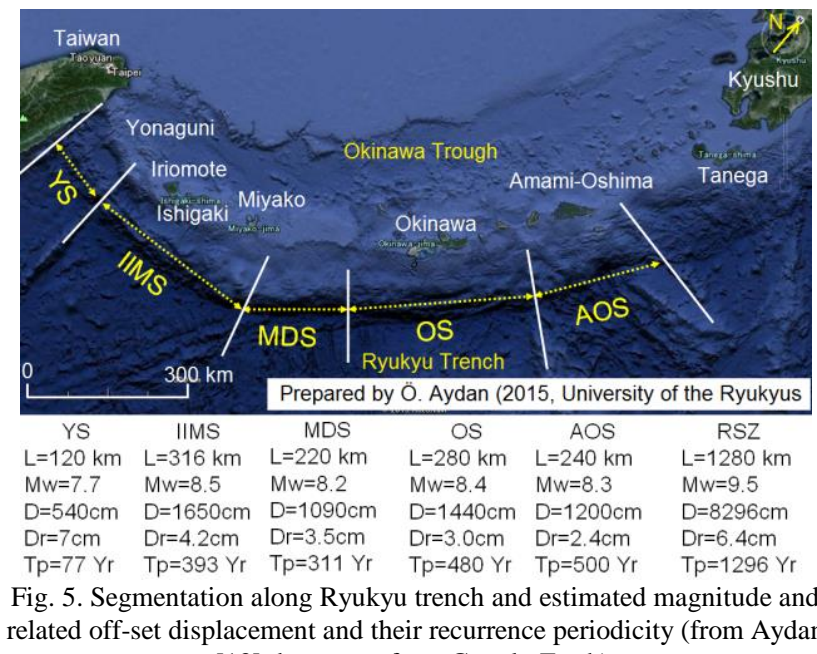
[13]; base map from Google-Earth).

Aydan [13] applied the relations to estimate the magnitude of the plate-boundary subduction earthquakes with a consideration of segmentation along the Ryukyu trench. Fig. 5 shows the segmentation along Ryukyu trench and estimated magnitude and related their off-set displacement and recurrence periodicity. The recurrence periodicity is computed from the off-set displacement and subduction rate of the segment measured from Global Positioning System (GPS). Fundamentally, five segments, namely, Yonaguni (YS), Iriomote-Ishigaki-Miyako (IIMS), Miyako Depression 
(MDS), Okinawa (OS) and Amami-Oshima (AOS), were identified in view of the seabed topography along the Ryukyu Trench. The longest segment is the Iriomote-Ishigaki-Miyako with a length of $316 \mathrm{~km}$ and estimated moment magnitude of the earthquake along this segment is 8.5. However, if the whole Ryukyu Trench (RSZ) was ruptured like the 2004 Off-Sumatra earthquake, it can produce a mega earthquake with a magnitude of 9.5. It is also interesting to note that the recurrence periodicity of the 9.5 earthquake is approximately 1300 years. Unfortunately, the oldest known earthquake occurred in 1664 with an unspecified magnitude along the Ryukyu Archipelago [14]-[16].

\section{TSUNAMI RISK}

The existence of tsunami boulders on several major islands in the Ryukyu Archipelago is well known ([14]-[17]) and some of them are shown in Fig. 6. The ages of the coral fossils on some tsunami boulders in the vicinity of Ishigaki and were determined by Goto et al [14] and they identified several periods: about 200, 500, 1000, 2000, and 2500 years ago on the tsunami boulders. They concluded that the tsunami occurred repeatedly in the Ryukyu Trench. There is a great interest if there could be some large events like the 2004 Off-Sumatra earthquake and tsunami along the Ryukyu Trench and Okinawa trough [14].

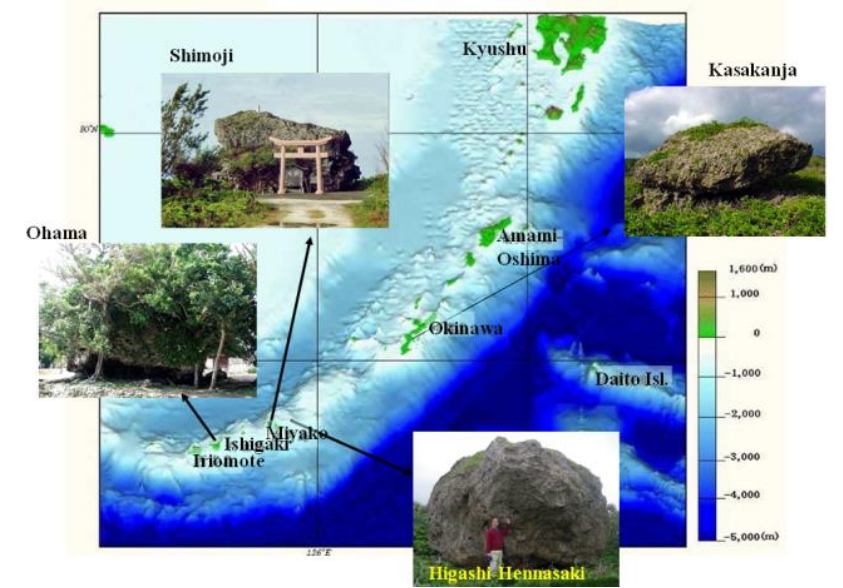

Fig. 6. Example huge tsunami boulders in major islands of the Ryukyu Archipelago (base map from 11th Regional Coast Guard Headquaters of Japan).

The authors and his colleagues have been investigating these tsunami boulders using site inspection, aerial photogrammetry technique utilizing drones and laser scanning technique. The authors attempt to infer the magnitude of mega-earthquakes, which resulted in huge tsunami boulders thrown over the cliffs (Fig. 7). The estimations would be also compared with other independent studies to check their validity. Furthermore, the implications of the estimations would be dicussed with the consideration of past seismicity of the Ryukyu Archipelago. In addition, the validity of the present seismic forces assumed in the construction of structures in Okinawa Prefecture is questioned.

One of major issues with tsunami boulders is how to differentiate from the boulders caused by tsunami and cliff failures due to toe-erosion and storm-waves during typhoons
[18]. Sometimes, boulders may be overthrown to higher elevations by strong storm-waves. For example, the Kasakanja boulder (see Fig. 6 and 7) was wrongly interpreted as typhoon-transported boulder [19]. In view of principles of hydro-mechanics, it would be unlikely to induce and transport such a huge boulder to the elevation of $12 \mathrm{~m}$ above the mean sea level by the strong storm-waves.

The authors have initiated an investigation program to quantify the geometry and position of tsunami boulders and topographical conditions in their close vicinity including the erosion state along the shoreline. The present observations were made on large tsunami boulders in Okinawa (Kasakanja), Miyako (Higashi-Hennasaki), Shimojiri (Obiwa) and Ishigaki (Ohama) Islands (Fig. 6). For this purpose, the authors have been utilizing aerial photogrammetry and laser scanning techniques [15]. Fig. 7 shows the utilization of a drone at Kasakanja site and the results of aerial photogrammetry. Although the tsunami boulders in Ishigaki, Miyako and Shimoji islands were initially believed to be due to the 1771 Meiwa earthquake with an estimated magnitude of 7.4, the recent studies indicated that they were much older [14], [20]. Particularly, the tsunami boulder in Shimoji Island is probably the largest in the world (Fig. 6). Table I gives the height and elevation of the tsunami boulders in selected locations. In addition, some large boulders of metamorphic origin and sandy tsunami deposits were observed within Ryukyu limestone layer during an excavation of a large engineering structure in Ishigaki Island [16]. These observations also imply that the events were cyclically occurring in Ryukyu Archipelago.

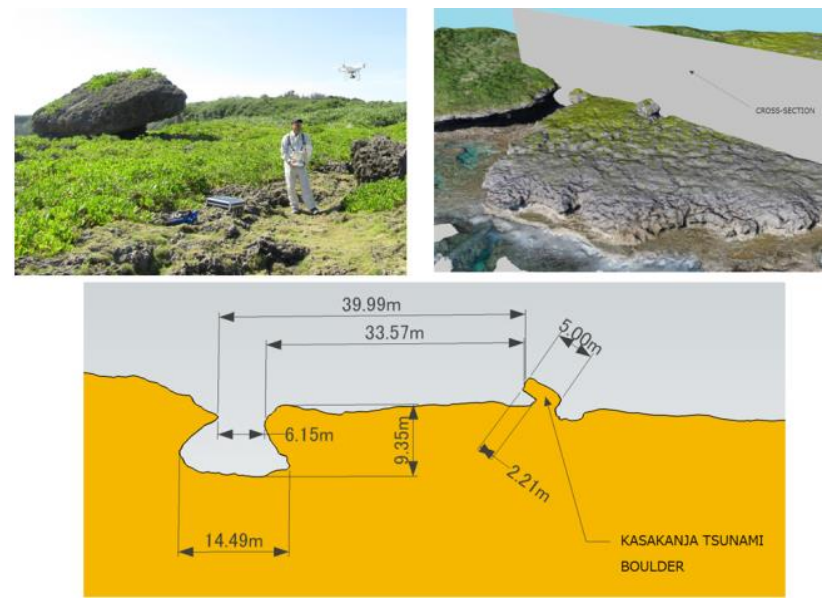

Fig. 7. The use of aerial phogrammetry technique utilizing a drone at Kasakanja site.

Aydan and Tokashiki [16] proposed a method of inference to estimate the magnitude of the mega-earthquake resulting in great tsunamis utilizing tsunami shore-line height defined in Fig. 8(a) and some empirical relations illustrated in Fig. 8(b). This method is applied to to estimate the magnitude for a present elevation and height of tsunami boulders given in Table I. The estimated moment magnitudes of earthquakes with the consideration of position of tsunami boulders are also given in Table I. Lower-bound (LB) values correspond to those estimated from present elevation height and upper-bound (UB) values obtained from the present elevation plus block height. The magnitude of the mega earthquakes along the Ryukyu Archipelago for lower bound ranges 
between 8.6 and 9.5 while it ranges between 9.1 and 9.7 for upper bound. The results clearly indicate that mega-earthquakes are also possible along the Ryukyu Archipelago and disaster-prevention measures must take this fact into account.

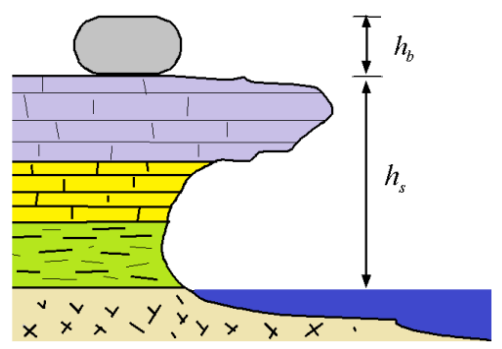

(a)

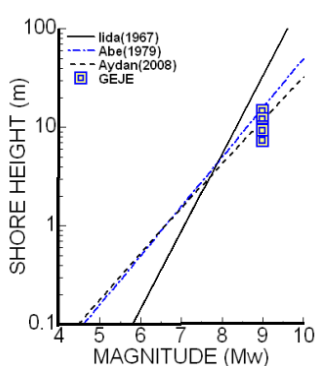

(b)
Fig. 8. (a) Illustration of shore height versus tsunami boulder height and (b) empirical relation between magnitude and shoreline height [10], [16].

TABLE I: ESTIMATED MAGNITUDE OF EARTHQUAKES FROM ELEVATION AND HEIGHT OF TSUNAMI BOULDERS

\begin{tabular}{|c|c|c|c|c|}
\hline Location & $\begin{array}{c}\text { Elevation } \\
(\mathrm{m})\end{array}$ & $\begin{array}{c}\text { Height } \\
(\mathrm{m})\end{array}$ & $\begin{array}{c}\text { Mw } \\
(\mathrm{LB})\end{array}$ & $\begin{array}{c}\text { Mw } \\
(\mathrm{UB})\end{array}$ \\
\hline Miyako-Hennazaki & 20 & 4 & 9.5 & 9.7 \\
\hline Shimoji & 12.5 & 9.0 & 9.0 & 9.5 \\
\hline Okinawa-Kasakanca & 12 & 3 & 9.0 & 9.2 \\
\hline Ishigaki-Ohama & 8.0 & 5.9 & 8.6 & 9.1 \\
\hline
\end{tabular}

LB: Lower Bound; UB: Upper Bound

\section{GEOTECHNICAL RISK}

\section{A. Landslides and Cliff Failures}

Most of landslides in Ryukyu Islands are associated with the Shimajiri formation. The natural slope landslides are mainly caused by the heavy rainfalls [21]. A recent landslide occurred at Kita-uebaru (or Asato) after a heavy torrential rainy period (Fig. 9). Tokashiki and Aydan [21] analysed this landslide and it was shown that the landslide was triggered by a heavy rainfall (Fig. 10). Besides the gravitational effects, there is no doubt that the increase of pore water pressure is the main mechanism to trigger this landslide. Additional causes may be the reduction of mechanical properties of Shimajiri mudstone by the increase of the water content. The landslide surface consists of bedding plane and an existing normal fault surface. The authors also simulated the post-failure motions of the landslide and it was found that the method proposed was capable of simulating the post-failure configuration and the time evolution of landslide body. Furthermore, it was shown that the actual strength properties of ground may be much more higher than those inferred from simple static residual strength circular sliding analyses.

The Shimajiri formation is generally overlaid by Ryukyu limestone formation. While rock slopes of Ryukyu limestone formation are generally stable, rockfalls may be caused by the erosion of underlaying soft Shimajiri formation resulting in overhanging slopes. Similar failures may also be induced along the steep sea cliffs of Ryukyu Islands.

The stability problems may arise in the form of bending failure, shearing failure and toppling failure depending upon the natural discontinuities of rock mass with toe erosion. The cantilever-like cliffs along the shores of Ryukyu Islands constituted by Ryukyu limestone formation are caused by the dissolution and/or erosion of limestone by sea waves, winds, river flow or percolating rain water and they may cause stability problems especially in urbanized areas along shorelines and riversides (Aydan and Tokashiki, 2010) Fig. 11(a) shows the restoration of the collapsed overhanging cliff along Route 331 in Nanjo City, which occurred on July 27, 2008 after a rainy period. The roadway closed to traffic for more than 9 months.

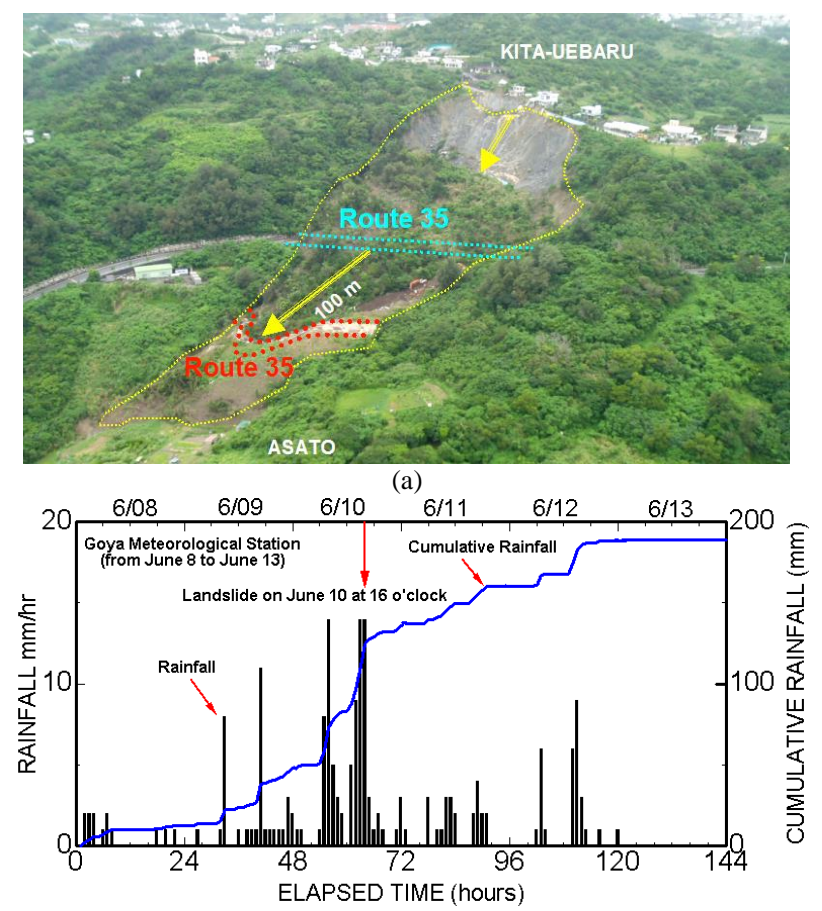

(b)

Fig. 9. (a) An aerial view of landslide area (b) Variation of rainfall [21].

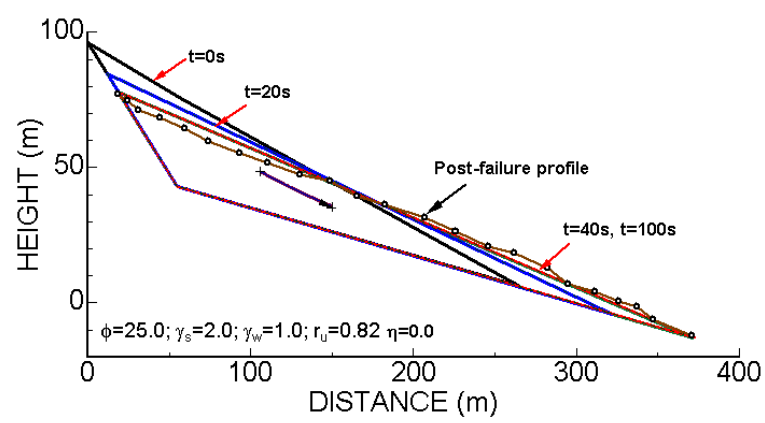

(a)

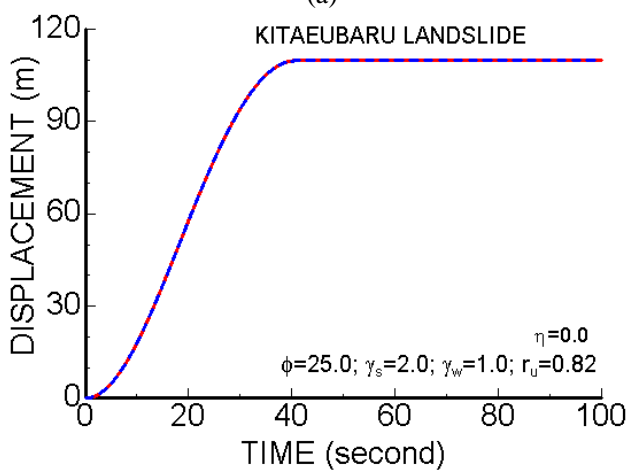

(b)

Fig. 10. (a) Deformed configuration at different time steps and (b) time-series of the motion of the center of the landslide body in Kita-Uebaru [21].

The observations were compared with estimations from the bending theory of cantilever beams proposed by the authors [21]. Fig. 11(b) shows the results of measurements of failed 
and stable Ryukyu limestone cliffs together with estimated stability bounds for different tensile strength of rock mass using the bending theory of cantilever beams. It is interesting to note that the in-situ tensile strength of rock mass should range between 0.25 and $1.0 \mathrm{MPa}$ if the presented theoretical model is applicable. The tensile strength of intact Ryukyu limestone specimens generally varies between 2 and $4 \mathrm{MPa}$. Therefore, the estimated in-situ tensile strength of rock mass is 0.06-0.25 times the tensile strength of intact rock.

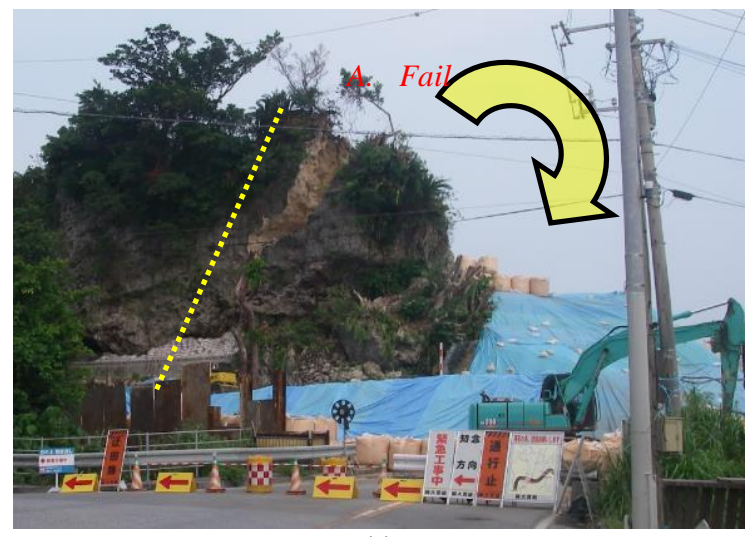

(a)

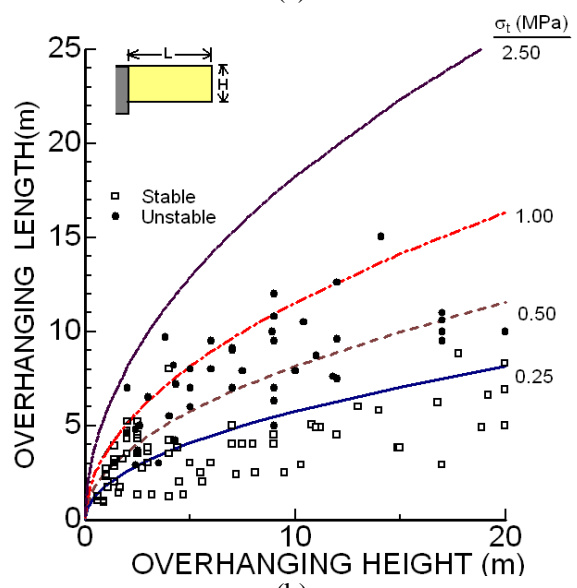

(b)

Fig. 11. (a) Cliff failure on Route 331 in Nanjo city and (b) Comparison of measured results of failed and stable cliffs with theoretical bounds [18], [22].

\section{B. Sinkholes}

The depth of natural caves in Ryukyu Islands is generally shallow and the compressive stress induced collapse of the caves is very rare. The failures are generally associated with the bending stresses. The stability of the cave can be analysed using some empirical, analytical and numerical techniques. On the basis of observations (Fig. 12) on the Karstic natural caves in Ryukyu limestone, four different stability categories defined for natural underground openings in Ryukyu limestone and it is updated to six categories as shown in Fig. 13(a) together with illustrations of each category of stability conditions [22]. Fig. 13(b) compares some empirical relations to evaluate the stability bounds. The coefficients of the empirical relations are given in Table II.

Karstic caves may present some engineering problems especially in urbanized areas along shorelines and riversides. The effect of karstic caves on the overall stability of the castle remains were investigated using empirical, analytical and static and dynamic numerical techniques by Aydan and Tokashiki [22]. In addition one-dimensional shaking table experiments on model caves were performed and the effect of cavity filling as a counter-measure was investigated. These investigations clearly demonstrated that the filling of cavities should be an effective measure to achieve the overall safety of superstructures.

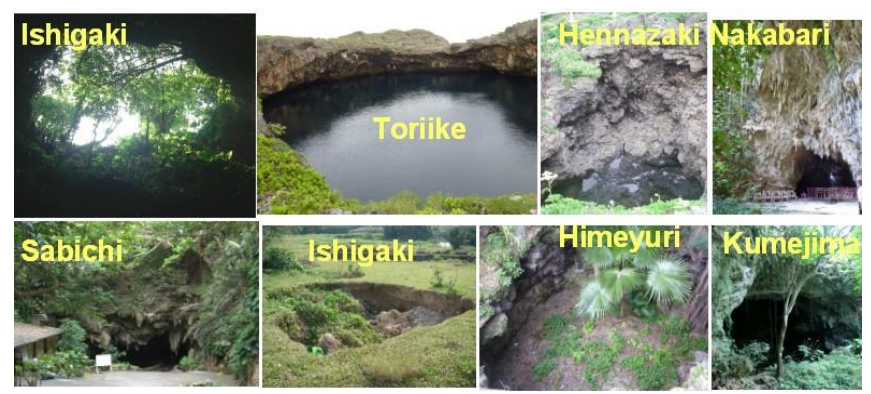

Fig. 12. Examples of sinkholes associated with karstic caves in several Islands of Ryukyu Archipelago.

\begin{tabular}{|c|c|c|c|c|}
\hline Category & State & $\frac{H_{f}}{H_{r}}$ & $\frac{B_{\varepsilon}}{B}$ & Comments \\
\hline I & & 0.0 & 0.0 & Opening locally and globally stable \\
\hline II & & $0.0-0.1$ & 0.0 & $\begin{array}{l}\text { Some rock block falls from roof. Opening globally } \\
\text { stable }\end{array}$ \\
\hline III & & $0.1 \cdot 0.3$ & 0.0 & $\begin{array}{l}\text { Block falls from roof and sidewalls into the opening } \\
\text { occur and the failure zone increases in size. Roof } \\
\text { height is higher than opening width. The failure } \\
\text { zone may increase in size with time. }\end{array}$ \\
\hline IV & & $0.3-0.7$ & 0.0 & $\begin{array}{l}\text { Considerable scale of falls and sliding of rock blocks } \\
\text { from the roof and sidewall of openings occur and } \\
\text { the failure zone larger in size. Roof height is much } \\
\text { higher than opening width. The failure zone may } \\
\text { increase reach ground surface in long-term }\end{array}$ \\
\hline V & 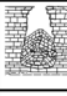 & $0.7 \cdot 1.0$ & $0.8 \cdot 1.0$ & $\begin{array}{l}\text { Failure zone reaches to ground surface and a small } \\
\text { size crater develops at ground surface. The } \\
\text { possibility of collapse zone may increase in size and } \\
\text { shoulder may fall into opening in long-term }\end{array}$ \\
\hline VI & & $=1.0$ & $>1.0$ & $\begin{array}{l}\text { Opening globally unstable. In other words, it is in a } \\
\text { total collapse state. Deep Sinkhole appear on the } \\
\text { ground surface. }\end{array}$ \\
\hline
\end{tabular}

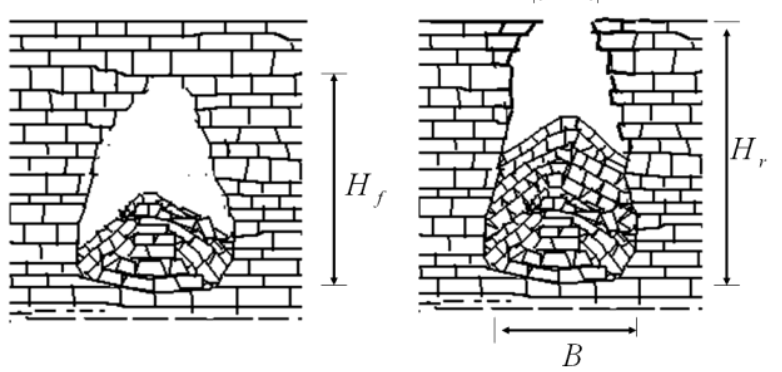

(a)

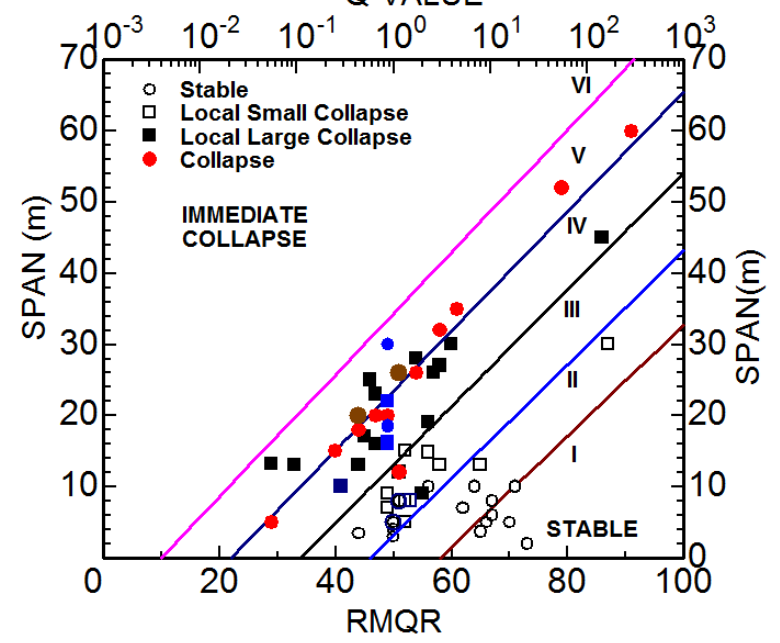

(b)

Fig. 13. (a) Categorization and (b) Comparison of empirical bounds for of state of karstic caves 
TABLE II: VALUES OF EMPIRICAL CONSTANTS

\begin{tabular}{ccccc}
\hline Lines & \multicolumn{2}{c}{$L=a \mathrm{RMQR}+b$} & \multicolumn{2}{c}{$L=a R M Q R^{b}$} \\
\cline { 2 - 5 } & $a$ & $b$ & 0.020 & 1.4 \\
I-II & 0.78 & -45.24 & 0.045 & 1.4 \\
II-III & 0.80 & -36.80 & 0.070 & 1.4 \\
III-IV & 0.82 & -27.88 & 0.095 & 1.4 \\
IV-V & 0.84 & -18.48 & 0.120 & 1.4 \\
V-VI & 0.86 & -8.60 & & \\
\hline
\end{tabular}

A new airport has been under construction in Ishigaki Island. Some karstic caves exist beneath the runway of the airport. These karstic caves are required to be protected for environmental concerns. The prefectural government decided to construct tunnels spanning over these caves. The most important aspect for designing the protection tunnels was how to determine the location and separation distance of footings of the protection lining, which should not be affected in case of the instability of existing caves in relation to the depth and size of the natural cavities. Aydan and Tokashiki [22] have performed laboratory experiments under static and dynamic conditions on the influence area above the caves. These experimental studies provided physical data on the optimum distance of footings as well as safety factors against potential instabilities. When the Futenma Base operated presently by USA Army is returned to Japan, it is expected to encounter similar problems and the cavity back-filling would be required.

\section{RISK OF SUPER-TYPHOONS AND ASSOCIATED DISASTERS}

Typhoons, which are also known as hurricanes or tropical cyclones, pass over the Ryukyu Archipelago every year and Okinawa is sometimes referred to as "Typhoon Alley". Typhoons are characterized by heavy torrential rains and storms. High sea-waves occur along shores, which may lead to failures of cliffs and other engineering structures. Furthermore, the strong winds have great impacts on tall engineering structures as well as light structures. They are characterized with winds with high velocity. One of the strongest typhoons was recorded in Miyako Island with a maximum wind velocity of $60.8 \mathrm{~m} / \mathrm{s}$ with an instantaneous wind speed of $85.3 \mathrm{~m} / \mathrm{s}$, which was the most powerful wind velocity in Japan in Sept. 4-6, 1966. This typhoon is also called Cora Typhoon [23] and this wind velocity is taken as the extreme limit of wind velocity for the design of pylons and tall structures such as super-rise buildings, towers, wind-turbines in Japan [24]. The possibility of super-typhoons is expected to increase as a result of global-warming and their locations would move further north in Northern Pacific. The paths of typhoons depend upon the climatic conditions such as the air pressure, temperature, humidity and topographic conditions and the rotation of the earth. Fig. 14 shows the paths of major typhoons between 1981-2000 and possible path depending upon the months [25] The average number of typhoons affecting the Ryukyu Archipelago is roughly 8-10 per year. Fig. 15 shows damage induced by recent great typhoons. Typhoons topples the utility poles and pylons, which may result in disruptions electricity power loss, They may even cause the collapse of seawalls due to high-waves as well as strong wind forces, damage to off-shore platforms. The Maemi typhoon in 2003 toppled or damaged many wind-turbines in a wind-turbine farm in Miyako Island.

The forces acting on the structures are also great importance. Stand-alone type accelerometers named as QV3-OAM-SYC and developed by the author [26] were utilized to measure the vibration of various buildings during strong winds including typhoons as well as earthquakes. Fig. 16 shows several examples of application to buildings in Ginowan City in Okinawa Island, Japan and some examples of accelerations records measured at the 3rd floor of a flat in the 5th story RC building during Typhoon No.8 on July 8, 2014. As noted from the figure, the typhoons result in very high horizontal accelerations on structures.

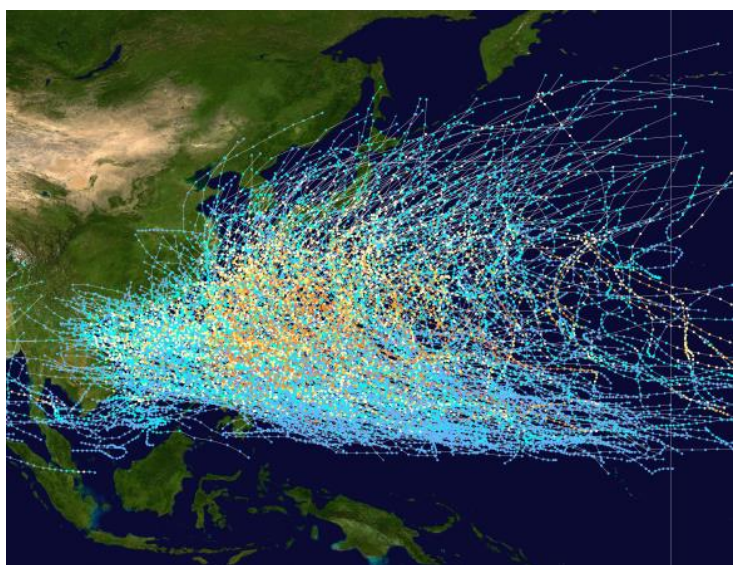

(A)

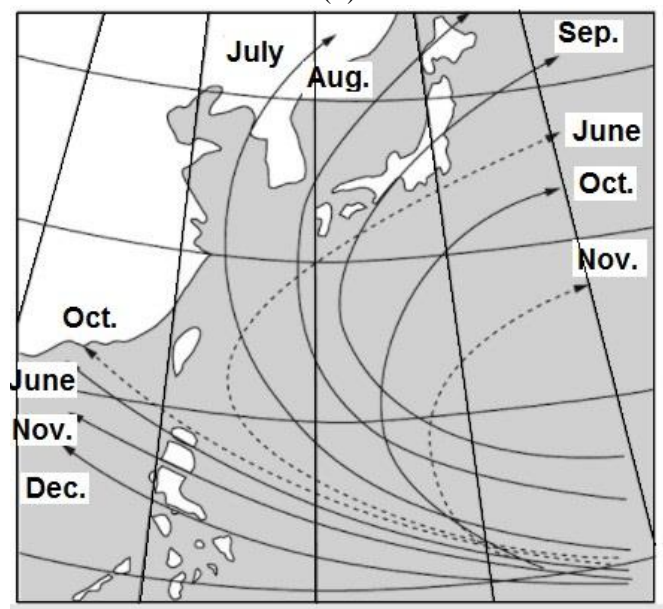

(b)

Fig. 14. (a) Paths of typhoons between 1981-2000 [23] and (b) Possible paths of typhoons according to the months in North Pacific [25].

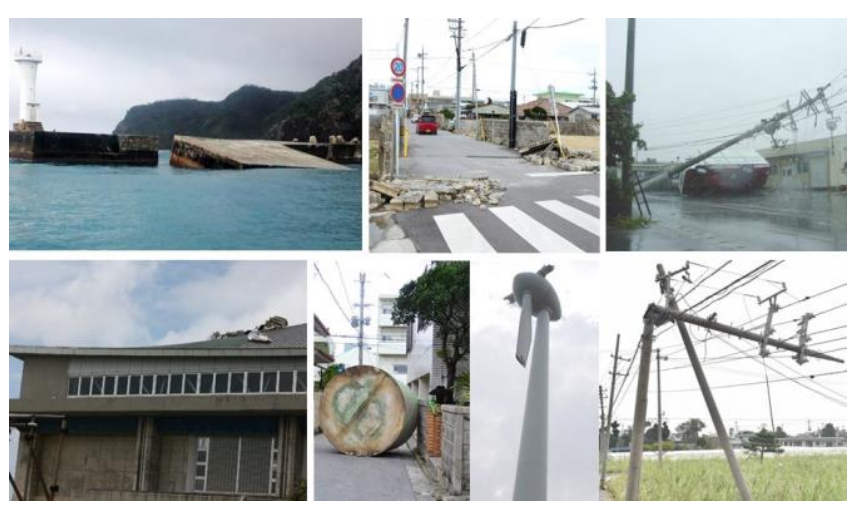

Fig. 15. Structural damage by recent great typhoons hit the Ryukyu Archipelago. 

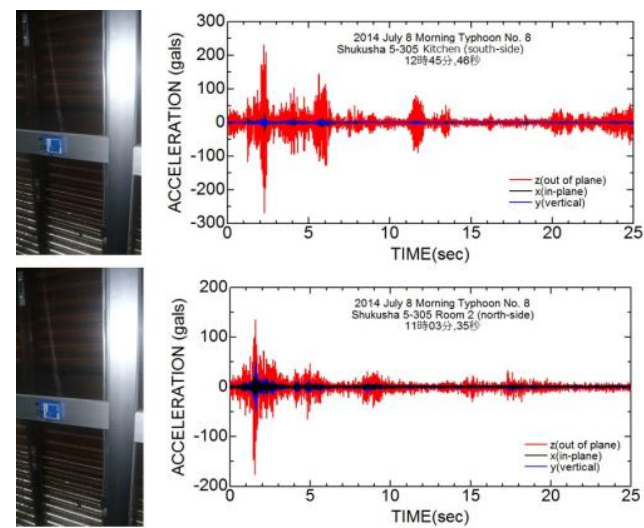

Fig. 16. Views of accelerometers attached to door and window aluminum panels of a flat in the 3rd floor of an RC building in Ginowan City and their responses of during Typhoon No. 8 on August 8, 2014 [26].

\section{CONCLUSIONS}

The author described his thoughts on the risk of natural disasters in the Ryukyu Archipelago. Some of conclusions from this study are as follow:

1) It is shown that the risk of mega-earthquakes and mega-tsunamis is quite high in Ryukyu Archipelago despite the common belief that the Okinawa Prefecture is an aseismic region. The mega-earthquakes up to Magnitude 9.7 is possible in view of the tsunami boulders distributed over the Ryukyu Archipelago while the segmentation of the Ryukyu trench implies risk of mega-earthquakes with a magnitude greater than 9.5.

2) The risk geotechnical natural disasters in Ryukyu Archipelago is landslides in Shimajiri formation and, cliff failures and sinkholes in Ryukyu limestone formation.

3) The Ryukyu Archipelago is also known as the " Typhoon Alley". The risk of natural disasters due to typhoons is quite high. The global warming is expected to increase the risk of super-scale typhoons in Ryukyu Archipelago. This may also result in the modification of design wind loads on structures in Japan.

\section{REFERENCES}

[1] K. Kizaki, "Geology and tectonics of the Ryukyu Islands," Tectonophysics, vol. 125, pp. 193-207, 1986.

[2] Ö. Aydan, Y. Ohta, M. Daido, H. Kumsar, M. Genis, N. Tokashiki, T. Ito, and M. Amini, "Chapter 15: Earthquakes as a rock dynamic problem and their effects on rock engineering structures," Advances in Rock Dynamics and Applications, Taylor and Francis Group, pp. 341-422, 2011.

[3] Ö. Aydan, "A stress inference method based on GPS measurements for the directions and rate of stresses in the earth' crust and their variation with time," Yerbilimleri, vol. 22, pp. 21-32, 2000.

[4] Geographical Information Authority of Japan. [Online]. Available: http://www.gsi.go.jp/

[5] Ö. Aydan, "The Possibility of earthquake prediction with the help of techniques of modern science and technology," Advanced Lecture Series, University of the Ryukyus, Disaster Prevention Research Center for Islands Region, p. 29, 2017.

[6] N. Tokashiki and Ö. Aydan, "The Off-Okinawa Island earthquake of February 27,2010," Earthquake Disaster Investigation Report, Japan Society of Civil Engineers, Earthquake Disaster Investigation Sub-Committee, 2010.

[7] Ö. Aydan, "Seismic characteristics of Turkish earthquakes," Turkish Earthquake Foundation, TDV/TR 97-007, 1997.

[8] Ö. Aydan, "Comparison of suitability of submerged tunnel and shield tunnel for subsea passage of Bosphorus," Geological Engineering Journal, vol. 25, no. 1, pp. 1-17, 2001.
[9] Ö. Aydan, "Inference of seismic characteristics of possible earthquakes and liquefaction and landslide risks from active faults," in Proc. the 6th National Conference on Earthquake Engineering of Turkey, Istanbul, vol. 1, pp. 563-574, 2007.

[10] Ö. Aydan, "Some thoughts on seismic and tsunami hazard potentials in Indonesia with a special emphasis on Sumatra Island," Journal of The School of Marine Science and Technology, vol. 6, no. 3, pp. 19-38, 2008.

[11] Ö. Aydan, "Ground motions and deformations associated with earthquake faulting and their effects on the safety of engineering structures," Encyclopedia of Sustainability Science and Technology, pp. 3233-3253, 2012.

[12] Ö. Aydan, "A critical testing of the applicability of some empirical relations used in the science and engineering of earthquakes through the 2011 Great East Japan Earthquake," Bulletin of Engineering Geology and the Environment, vol. 74, no. 4, pp. 1243-1254, 2015.

[13] Ö. Aydan, "The possibility of mega earthquakes along the Ryukyu Archipelago and their prediction," Disaster Prevention Mini Symposium, University of the Ryukyus, Disaster Prevention Research Center for Islands Region, p. 29, 2015.

[14] K. Goto, T. Kawana, and F. Imamura, "Historical and geological evidence of boulders deposited by tsunamis, southern Ryukyu islands, Japan," Earth-Science Reviews, vol. 102, pp. 77-99, 2010.

[15] Ö. Aydan and N. Tokashiki, "Some damage observations in Ryukyu limestone caves of Ishigaki and Miyako Islands and their possible relations to the1771 Meiwa Earthquake," J. of The School of Marine Sci. and Tech., Tokai University, vol. 5, no. 1, pp. 23-39, 2007.

[16] Ö. Aydan and N. Tokashiki, "Tsunami Boulders and Their Implications on the Mega Earthquake Potential along Ryukyu Archipelago, Japan," Bulleting of Engineering Geology and Environment, 2018.

[17] T. Nakata and T. Kawana, Historical and Prehistorical Large Tsunamis in the Southern Ryukyus, Japan, in Tsunami: Progress in Prediction, Disaster Prevention and Warning, pp. 211-222, Kluwer Academic Publishers, Netherlands, 1995

[18] N. Tokashiki and Ö. Aydan, "The stability assessment of overhanging Ryukyu limestone cliffs with an emphasis on the evaluation of tensile strength of Rock Mass," Journal of Geotechnical Engineering, JSCE, vol. 66, no. 2, pp. 397-406, 2010.

[19] T. Kawana, "Yuisa-Ishi on the reef crest off Chinen, Nanjo city, Okinawa Island: Coralline block transported by the Ruth Typhoon in 1951," Bulletin of Faculty of Education, University of the Ryukyus, vol. 72, pp. 135-139, 2008.

[20] D. Araoka, Y. Yokoyama, A. Suzuki, K. Goto, K. Miyagi, K Miyazawa, H. Matsuzaki, and H. Kawahata, "Tsunami recurrence revealed by Porites coral boulders in the southern Ryukyu Islands, Japan," Geology, vol. 41, pp. 919-922, 2013.

[21] N. Tokashiki and Ö. Aydan, "Kita-Uebaru natural rock slope failure and its back-analysis," Environmental Earth Sciences, 2010.

[22] Ö. Aydan and N. Tokashiki, "A comparative study on the applicability of analytical stability assessment methods with numerical methods for shallow natural underground openings," in Proc. the 13 International Conference of the International Association for Computer Methods and Advances in Geomechanics, Melbourne, Australia, pp. 964-969, 2011.

[23] Wikipedia, Typhoon. [Online]. Available: https://en.wikipedia.org/wiki/Typhoon

[24] Ö. Aydan, S. Komura, S. Ebisu, and T. Kawamoto, "A unified design method for rock anchor foundations of super-high pylons," The Int. Workshop on Rock Foundation of Large-scaled Structures, ISRM, Tokyo, pp. 279-284, 1995.

[25] Japan Meteorological Agency (JMA). [Online]. Available: http://www.jma.go.jp/

[26] Ö. Aydan, "Lessons from the recent great earthquakes on the performance of buildings under different geotechnical environments," in Proc. the 2nd International Sustainable Building Symposium, Ankara, pp. 3-20, 2015.

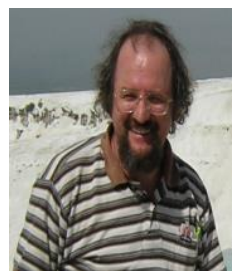

Ömer Aydan was born in 1955, and studied mining engineering at the Technical University of Istanbul, Turkey (B.Sc., 1979), rock mechanics and excavation engineering at the University of Newcastle upon Tyne, UK (M.Sc., 1982), and finally received his Ph.D. in geotechnical engineering from Nagoya University, Japan in 1989. He worked at Nagoya University as a research associate (1987-1991), and at the Dept 
of Marine Civil Engineering at Tokai University, first as assistant professor (1991-1993), then as associate professor (1993-2001), and finally as professor (2001-2010). He then became Professor of the Institute of Oceanic Research and Development at Tokai University, and is currently professor at the University of Ryukyus, Department of Civil Engineering, Nishihara, Okinawa, Japan. Ömer Aydan has played an active role on numerous ISRM,
JSCE, JGS, SRI and Rock Mech. National Group of Japan committees, and has organized several national and international symposia and conferences. He was also made honorary professor in earth science by Pamukkale University in 2008. 